\title{
PPFIBP1 wt Allele
}

National Cancer Institute

\section{Source}

National Cancer Institute. PPFIBP1 wt Allele. NCI Thesaurus. Code C101495.

Human PPFIBP1 wild-type allele is located in the vicinity of 12p12.1 and is approximately

$172 \mathrm{~kb}$ in length. This allele, which encodes liprin-beta-1 protein, is involved in the modulation of protein-protein interactions. 